\title{
PENGARUH PENGGUNAAN KONSENTRAT DALAM BENTUK PELET DAN MASH PADA PAKAN DASAR RUMPUT LAPANGAN TERHADAP PALATABILITAS DAN KINERJA PRODUKSI KELINCI JANTAN
}

\author{
THE EFFECT OF PELLET AND MASH CONCENTRATES UTILIZATION ON FEED \\ PALATABILITY AND PERFORMANCE OF RABBIT BUCKS FED NATIVE GRASS AS BASSAL \\ DIET
}

\author{
Sidiq Setyo Nugroho, Subur Priyono Sasmito Budhi, dan Panjono* \\ Fakultas Peternakan, Universitas Gadjah Mada, Jl. Fauna No. 3, Bulaksumur, Yogyakarta, 55281
}

\section{INTISARI}

Penelitian ini bertujuan untuk pengaruh penggunaan konsentrat dalam bentuk pelet dan mash pada pakan dasar rumput lapangan terhadap palatabilitas dan kinerja produksi kelinci jantan. Penelitian ini menggunakan 20 ekor kelinci

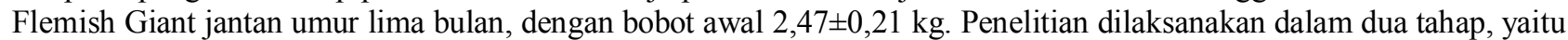
uji palatabilitas dan uji kinerja produksi. Uji palatabilitas dilaksanakan selama 10 hari. Seluruh kelinci diberi konsentrat bentuk pellet dan mash secara bebas memilih. Uji kinerja produksi dilakukan selama 40 hari. Kelinci dibagi secara random ke dalam dua kelompok perlakuan, yaitu kelompok yang diberi konsentrat dalam bentuk pelet dan mash. Hasil uji palatabilitas menunjukkan bahwa konsumsi pelet lebih tinggi $(\mathrm{P}<0,05)$ daripada mash. Konsumsi pelet dan mash pada uji palatabilitas berturut-turut adalah $24,04 \pm 2,25$ dan $13,69 \pm 2,37 \mathrm{~g} /$ ekor/hari. Hasil uji kinerja produksi menunjukkan bahwa konsumsi pakan kelinci yang diberi konsentrat dalam bentuk pelet dan mash berbeda tidak nyata, tetapi pertambahan bobot badan harian $(\mathrm{PBBH})$ kelinci yang diberi konsentrat dalam bentuk pelet lebih tinggi $(\mathrm{P}<0,05)$ daripada yang diberi konsentrat dalam bentuk mash, sehingga konversi pakan dan feed cost per gain kelinci yang diberi pakan pelet lebih rendah $(\mathrm{P}<0,05)$ daripada yang diberi pakan mash. Konsumsi pakan, $\mathrm{PBBH}$, konversi pakan, dan feed cost per gain kelinci yang diberi konsentrat dalam bentuk pelet dan mash berturut-turut adalah 120,10 $\pm 15,81$ dan $121,68 \pm 17,74 \mathrm{gBK} / \mathrm{kgBB} / \mathrm{hari}, 17,40 \pm 5,91$ dan $10,22 \pm 3,09 \mathrm{~g} / \mathrm{hari}, 7,31 \pm 1,61$ dan $12,84 \pm 3,75$, serta $43,65 \pm 9,63$ dan $72,32 \pm 21,08 \mathrm{Rp} / \mathrm{g}$. Bobot dan persentase karkas, bobot daging dan tulang, serta perbandingan daging dan tulang (MBR) kelinci yang diberi konsentrat dalam bentuk pelet dan mash berbeda tidak nyata. Bobot karkas, persentase karkas, bobot daging, bobot tulang, serta MBR kelinci yang diberi konsentrat dalam bentuk pelet dan mash berturut-turut adalah $1.569,40 \pm 136,99$ dan $1.473,00 \pm 123,45 \mathrm{~g}, 49,28 \pm 1,40$ dan $49,45 \pm 1,96 \%, 1.091,80 \pm 131,92$ dan $1.011,75 \pm 78,61 \mathrm{~g}$, $477,90 \pm 38,76$ dan $461,25 \pm 56,86 \mathrm{~g}$, serta $2,30 \pm 0,36$ dan 2,21 $\pm 0,22$. Disimpulkan bahwa palatabilitas konsentrat dalam bentuk pelet lebih baik daripada bentuk mash. Konsentrat dalam bentuk pelet lebih efisien untuk pertumbuhan kelinci daripada konsentrat dalam bentuk mash.

(Kata kunci: Kelinci, Pelet, Mash, Palatabilitas, Kinerja produksi)

\section{ABSTRACT}

This research was conducted to observe the effect of pellet and mash concentrates utilization on feed palatability and performance of rabbit bucks fed native grass as bassal diet. Twenty heads of five months old Flemish Giant rabbit with initial body weight of $2.47 \pm 0.21 \mathrm{~kg}$ were used in this study. Research was divided into two phases, i.e. palatability and performance tests. The palatability test was conducted for 10 days. All animal were offered pellet and mash concentrates as free choice feeding. The performance test was conducted for 40 days. Animal were randomly divided into two treatment groups, i.e. pellet and mash concentrate. Palatability test result showed that consumption of pellet was higher $(P<0.05)$ than that of mash. The pellet and mash consumptions during palatability test were $24.04 \pm 2.25 \mathrm{vs}$ $13.69 \pm 2.37 \mathrm{~g} / \mathrm{head} /$ day, respectively. Performance test result showed that there was no significant difference feed intake between pellet and mash. However, the average daily gain (ADG) of animal fed pellet concentrate were higher $(P<0.05)$ than that of animal fed mash concentrate so that feed conversion ratio $(F C R)$ and feed cost per gain of animal fed pellet concentrate were lower $(P<0.05)$ than those of animal fed mash concentrate. The feed intake, $A D G, F C R$ and feed cost per gain of animal fed pellet and mash concentrates were $120.10 \pm 15.81$ and $121.68 \pm 17.74 \mathrm{gDM} / \mathrm{kgBW} / \mathrm{day}$, $17.40 \pm 5.91$ and $10.22 \pm 3.09 \mathrm{~g} /$ day, $7.31 \pm 1.61$ and $12.84 \pm 3.75$, and $43.65 \pm 9.63$ and $72.32 \pm 21.08 \mathrm{IDR} / \mathrm{g}$. There was no significant different carcass weight and percentage, meat and bone weights and meat bone ratio between animal fed pellet and mash concentrates. Carcass weight, carcass percentage, meat weight, bone weight and meat bone ratio of

\footnotetext{
*Korespondensi (corresponding author):

Telp. +62 8132802 2087, E-mail: panjono@gadjahmada.edu
} 
animal fed pellet and mash concentrates were $1569.40 \pm 136.99$ and $1473.00 \pm 123.45 \mathrm{~g}, 49.28 \pm 1.40$ and $49.45 \pm 1.96 \%$, $1091.80 \pm 131.92$ and $1011.75 \pm 78.61 \mathrm{~g}, 477.90 \pm 38.76$ dan $461.25 \pm 56.86 \mathrm{~g}$, serta $2.30 \pm 0.36$ and 2.21 \pm 0.22 , respectively. It is concluded that palatability of pellet concentrate is better than that of mash concentrate. Pellet is more efficient to improve rabbit growth than mash.

(Keywords: Rabbit, Pellet, Mash, Palatability, Performance)

\section{Pendahuluan}

Kelinci menjadi ternak pilihan karena pakannya tidak bersaing dengan kebutuhan manusia, maupun ternak industri yang intensif. Kombinasi antara modal kecil, jenis pakan yang mudah dan perkembangbiakan yang cepat, menjadikan kelinci masih sangat relevan dan cocok sebagai alternatif usaha bagi petani miskin yang tidak memiliki lahan luas dan tidak mampu memelihara ternak besar (Sitorus et al., 1982).

Salah satu faktor produksi yang memakan banyak biaya adalah pakan. Bagian yang penting dalam faktor pakan tersebut adalah kualitas dan efektifitas dalam pemberian pakan. Selama ini sebagian besar peternak memberikan konsentrat dalam bentuk basah. Pakan basah ini tidak bertahan lama, sehingga pada setiap pemberian pakan, pakan tersebut harus cepat habis sebelum pakan menjadi basi. Tumbuhnya jamur pada pakan yang basi bisa mengundang penyakit bagi kelinci. Sebagai jalan keluar dari permasalahan tersebut, dapat diberikan pakan dalam bentuk kering.

Pakan kering dapat diberikan dalam bentuk pelet atau mash. Pelet khusus untuk kelinci sangat penting, karena kualitas yang lebih homogen dan tetap sehingga peternak bisa menyimpan pakan untuk jangka waktu lama (Manshur, 2009). Bentuk pakan kering selain pelet adalah mash. Mash adalah pakan campuran yang disusun dari berbagai macam bahan pakan tetapi tidak dibentuk menjadi pelet. Namun demikian, penelitian mengenai bentuk pakan belum banyak dilakukan, oleh karena itu penelitian ini dilaksanakan.

\section{Materi dan Metode}

Kelinci yang digunakan dalam penelitian ini adalah kelinci Flemish Giant jantan umur \pm 5 bulan dengan bobot awal $2,47 \pm 0,21 \mathrm{~kg}$ sebanyak 20 ekor. Kelinci dipelihara di dalam kandang individu yang terbuat dari bambu dan kayu dilengkapi tempat pakan dan minum terbuat dari plastik. Ukuran kandang panjang $\times$ lebar $\times$ tinggi adalah $75 \times 65 \times 60$ $\mathrm{cm}$.

Bahan pakan yang digunakan dalam penelitian adalah hijauan dan konsentrat. Hijauan yang diberikan berupa rumput lapangan. Konsentrat dibuat dari campuran ampas tahu basah, bekatul padi, jagung giling, bungkil kedelai, tepung gaplek, tetes tebu, tepung daun singkong, garam dapur, dan mineral.

Pembuatan konsentrat dimulai dengan menghaluskan bahan pakan berupa bungkil kedelai dan jagung dengan mesin giling tepung dengan diameter lubang screen $2 \mathrm{~mm}$. Tepung daun singkong dibuat dengan cara menjemur daun singkong rajangan hingga kering, setelah kering ditumbuk dan diayak. Daun singkong yang digunakan adalah daun yang dipetik dari batang tanaman singkong setelah panen. Singkong yang dipilih dari tanaman singkong mentega (umbi berwarna agak kuning). Tangkai daun singkong dihilangkan, setelah kering urat daun dibuang dan hanya dipakai lembaran daunnya saja. Bahan pakan dicampur sesuai komposisi tanpa tambahan air, kemudian dikukus selama $1 / 2$ jam. Setelah dikukus sebagian hasil kukusan dicetak menjadi bentuk pelet dengan mesin berdiameter lubang $8 \mathrm{~mm}$ dan tenaga penggerak elektromotor $1 / 2$ PK, kemudian dijemur di bawah sinar matahari hingga kering. Sebagian yang lain langsung dijemur di bawah sinar matahari hingga kering dan terbentuk mash. Harga konsentrat dalam bentuk pelet adalah $\mathrm{Rp} 5.384,62 / \mathrm{kg}$ dan dalam bentuk mash adalah Rp5.076,92/kg.

Hasil pengujian kandungan nutrisi menggunakan uji proksimat yang meliputi pengujian kandungan bahan kering, protein kasar, serat kasar, lemak kasar, dan abu. Kandungan nutrien hasil uji proksimat terhadap bahan pakan dapat dilihat pada Tabel 1.

Hasil pengujian hardness menggunakan hardness tester diperoleh hasil bahwa pelet pecah pada tekanan $11,86 \pm 2,48$ Newton. Hasil pengujian durability menggunakan mesin Rotab produksi W.S. Tyler dengan penggerak elektromotor dengan putaran mesin $1425 \mathrm{rpm}$ diperoleh pellet durability index 0,99 .

Sebelum penelitian dimulai, dilakukan adaptasi. Pada masa ini, kelinci dikondisikan pada suasana lingkungan penelitian agar konsumsi pakannya stabil. Kelinci hanya diberikan pakan rumput lapangan. Masa adaptasi dinyatakan selesai setelah kelinci tidak ada yang mengalami masalah kesehatan dan makan dengan stabil, berlangsung selama 7 hari. Setelah masa adaptasi, penelitian dilakukan dengan 2 tahap, yaitu tahap uji palatabilitas dan kinerja produksi. Uji palatabilitas berlangsung 
Tabel 1. Kandungan nutrien rumput lapangan dan konsentrat yang digunakan dalam penelitian (\% BK) (nutrient composition of native grass and concentrate (\% DM) used in the study)

\begin{tabular}{lccrccl}
\hline \hline \multicolumn{1}{c}{ Bahan pakan (feedstuff) } & BK & PK & \multicolumn{1}{c}{ SK } & LK & Abu (ash) & BETN \\
\hline Konsentrat (concentrate) & 89,38 & 17,93 & 9,57 & 3,43 & 11,24 & 57,83 \\
Rumput lapangan (native grass) & 26,34 & 12,99 & 28,45 & 2,03 & 14,39 & 42,14 \\
\hline BK: bK
\end{tabular}

BK: bahan kering (dry matter), PK: protein kasar (crude protein), SK: serat kasar (crude fiber), LK: lemak kasar (ether extract), BETN: bahan ekstrak tanpa nitrogen (nitrogen free extract).

selama 10 hari. Setiap kelinci diberikan pakan dasar dan konsentrat. Pakan dasar yang berupa rumput lapangan diberikan terbatas sebanyak $150 \mathrm{~g}$ as fed/ekor/hari setiap hari dan diasumsikan rumput dimakan habis. Konsentrat dalam bentuk pelet dan mash diberikan secara ad libitum dengan metode free choice feeding.

Uji kinerja produksi berlangsung selama 40 hari. Kelinci dibagi secara acak menjadi dua kelompok. Kedua kelompok kelinci diberi pakan dasar rumput lapangan sebanyak $150 \mathrm{~g}$ as fed/ekor/hari dan diasumsikan rumput dimakan habis. Kelompok pertama diberi konsentrat dalam bentuk pelet dan kelompok kedua diberi konsentrat dalam bentuk mash. Konsentrat diberikan secara $a d$ libitum.

Data yang diamati meliputi kinerja pertumbuhan dan hasil karkas. Kinerja pertumbuhan yang diukur meliputi konsumsi pakan, konsumsi nutrien, PBBH, konversi pakan, dan feed cost per gain.

Konsumsi pakan adalah jumlah bahan kering pakan yang dikonsumsi ternak setiap hari dan diperoleh dengan menghitung selisih antara jumlah pemberian dan sisa pakan. Konsumsi nutrien dihitung berdasarkan konsumsi pakan dan kandungan nutrien masing-masing bahan pakan. Pertambahan bobot badan harian diperoleh dengan menghitung selisih bobot badan awal dan akhir dibagi dengan jarak (hari) antara penimbangan awal dan penimbangan akhir. Konversi pakan didapat dengan cara menghitung konsumsi pakan dibagi dengan PBBH. Feed cost per gain adalah biaya pakan untuk setiap penambahan bobot badan dan didapat dengan cara menghitung konsumsi pakan dikalikan dengan harga pakan dibagi dengan $\mathrm{PBBH}$.

Data hasil karkas yang diambil antara lain bobot potong, bobot karkas, persentase karkas, bobot daging, bobot tulang, serta perbandingan daging dan tulang. Persentase karkas diperoleh dengan membagi bobot karkas dengan bobot potong dikalikan $100 \%$. Perbandingan daging dan tulang diperoleh dengan membagi bobot daging dengan bobot tulang yang dihasilkan dari setiap ekor kelinci. Penimbangan dilakukan dengan timbangan digital merek Idealife dengan kapasitas $5 \mathrm{~kg}$ dan kepekaan $1 \mathrm{~g}$.
Data yang diperoleh dianalisis menggunakan independent sample t-test. Khusus untuk ADG dianalisis dengan analisis kovariansi dengan bobot awal sebagai kovariat.

\section{Hasil dan Pembahasan}

\section{Palatabilitas}

Perubahan konsumsi pelet dan mash selama uji palatabilitas tersaji pada Tabel 2. Konsumsi pelet dari hari ke hari semakin meningkat. Pada hari ke-1 dan ke-2 konsumsi pelet dan mash berbeda tidak nyata. Pada hari ke-3 hingga hari ke-9 konsumsi pelet lebih tinggi $(\mathrm{P}<0,05)$ dibanding konsumsi mash. Pada hari ke-10 konsumsi pelet jauh lebih tinggi $(\mathrm{P}<0,01)$ dibanding konsumsi mash. Dari hari ke hari terdapat peningkatan kesukaan terhadap tipe pakan yang menunjukkan bahwa kelinci membutuhkan waktu untuk beradaptasi dan memilih pakan yang disukainya.

Rerata konsumsi pelet dan mash selama uji palatabilitas berlangsung beturut-turut adalah $26,2 \pm 9,058$ dan $14,92 \pm 10,33 \mathrm{gBK} / \mathrm{kgBB} /$ hari. Rerata konsumsi pelet lebih tinggi $(\mathrm{P}<0,05)$ daripada mash. Hasil uji palatabilitas menyatakan bahwa kelinci lebih menyukai konsentrat dalam bentuk pelet $(\mathrm{P}<0,01)$ daripada konsentrat dalam bentuk mash. Hal ini sesuai dengan NRC (1977) yang menyatakan bahwa kelinci lebih menyukai pakan dalam bentuk pelet daripada dalam bentuk mash.

\section{Kinerja produksi}

Tabel 3 menunjukkan bahwa konsumsi pakan kelinci yang diberi konsentrat dalam bentuk pelet berbeda tidak nyata dibanding kelinci yang diberi pakan mash. Konsumsi pakan kelinci pada penelitian ini sudah memenuhi kebutuhan. Kelinci muda dalam masa pertumbuhan membutuhkan 110130 g pakan per hari (Wiseman, 1987).

Konsumsi nutrien kedua kelompok kelinci berbeda tidak nyata (Tabel 4). Hal ini disebabkan karena komposisi nutrien pakan yang diberikan sama dan jumlah konsumsi pakannya juga sama (Tabel 1 dan 3).

Pertambahan bobot badan harian kelinci yang diberi konsentrat pelet lebih tinggi $(\mathrm{P}<0,05)$ 
Tabel 2. Konsumsi konsentrat harian (gBK/kgBB/hari) kelinci selama uji palatabilitas (daily feed consumption $(g D M / k g B W / d a y)$ of rabbit during palatability test)

\begin{tabular}{cclc}
\hline \hline Hari (day) & Pelet (pellet) & \multicolumn{1}{c}{ Mash } & Signifikansi \\
\hline 1 & $24,98 \pm 10,48$ & $19,78 \pm 12,40$ & ns \\
2 & $21,59 \pm 8,43$ & $13,64 \pm 10,16$ & ns \\
3 & $21,69 \pm 6,10$ & $11,68 \pm 8,58$ & $*$ \\
4 & $24,53 \pm 8,67$ & $11,86 \pm 7,63$ & $*$ \\
5 & $22,36 \pm 8,03$ & $12,04 \pm 10,16$ & $*$ \\
6 & $22,62 \pm 7,69$ & $13,50 \pm 8,80$ & $*$ \\
7 & $22,24 \pm 8,56$ & $14,09 \pm 9,91$ & $*$ \\
8 & $25,82 \pm 9,20$ & $13,77 \pm 10,38$ & $*$ \\
9 & $26,77 \pm 9,85$ & $12,08 \pm 8,10$ & $* *$ \\
10 & $27,80 \pm 6,07$ & $14,42 \pm 8,70$ & \\
Rerata (average) & $24,04 \pm 2,25$ & $13,69 \pm 2,37$ & \\
\hline
\end{tabular}

${ }^{\overline{\mathrm{ns}}}$ Non signifikan (not significant); ${ }^{*} \mathrm{P}<0,05 ; * * \mathrm{P}<0,01$.

Tabel 3. Kinerja pertumbuhan kelinci jantan yang diberi konsentrat dalam bentuk pelet dan mash (growth performance of rabbit bucks fed pellet and mash concentrates)

\begin{tabular}{|c|c|c|c|}
\hline Variabel (variable) & Pelet (pellet) & Mash & Sig. \\
\hline Bobot awal (g) (initial weight $(g)$ ) & $2.490,00 \pm 197,61$ & $2.566,25 \pm 162,74$ & \\
\hline Konsumsi pakan (gBK/kgBB/hari) (feed intake (gDM/kgBW/day)) & $120,10 \pm 15,81$ & $121,68 \pm 17,74$ & ns \\
\hline PBBH (g/hari) $(A D G(g /$ day $))$ & $17,40 \pm 5,91$ & $10,22 \pm 3,09$ & * \\
\hline Konversi pakan (Feed Conversion Ratio) & $7,31 \pm 1,61$ & $12,84 \pm 3,75$ & * \\
\hline Feed cost per gain $(\mathrm{R}$ & $43,65 \pm 9,63$ & $72,32 \pm 21,08$ & * \\
\hline
\end{tabular}

${ }^{\mathrm{ns}}$ Non signifikan (not significant); ${ }^{*} \mathrm{P}<0,05$.

Tabel 4. Konsumsi nutrien kelinci jantan yang diberi konsentrat dalam bentuk pelet dan $m a s h(\mathrm{gBK} / \mathrm{kgBB} / \mathrm{hari})$ (rabbit nutrient intake ( $g D M / \mathrm{kgBW} /$ day) fed pellet and mash concentrates)

\begin{tabular}{lccc}
\hline \hline \multicolumn{1}{c}{ Nutrien (nutrient) } & Pelet (pellet) & Mash & Sig. \\
\hline Protein $(\mathrm{gBK} / \mathrm{kgBB} /$ hari) (protein $(\mathrm{gDM} / \mathrm{kgBW} /$ day $))$ & $26,49 \pm 2,83$ & $26,77 \pm 3,18$ & ns \\
Serat $(\mathrm{gBK} / \mathrm{kgBB} /$ hari) $($ fiber $(\mathrm{gDM} / \mathrm{kg}$ W/day) $)$ & $22,64 \pm 1,51$ & $22,79 \pm 1,70$ & ns \\
Gross energy (kkal/kgBB/hari) $^{1}$ & $582,67 \pm 63,46$ & $588,98 \pm 71,20$ & ns \\
\hline
\end{tabular}

${ }^{n \mathrm{~ns}}$ Non signifikan (not significant).

${ }^{1}$ Protein: 5,6 kkal/g, Lipid 9,4 kkal/g, Karbohidrat 4,1 kkal/g (Furuichi, 1988).

daripada yang diberi konsentrat dalam bentuk mash (Tabel 3). Hal ini sesuai dengan hasil penelitian Fomunyam dan Ndoping (2000) yang menyatakan bahwa PBBH kelinci yang diberi pakan dalam bentuk pelet jauh lebih tinggi $(\mathrm{P}<0,01)$ daripada yang diberi pakan mash.

Pertambahan bobot badan harian yang lebih tinggi pada pakan pelet tersebut dimungkinkan terjadi karena perbedaan kecernaan di antara kedua jenis konsentrat. Hal ini berhubungan erat dengan retention time (lama waktu pakan menempati saluran pencernaan). Pakan dalam bentuk pelet lebih lama tinggal dalam saluran pencernaan karena diperlukan waktu untuk memecah butiran-butiran pelet yang masuk ke dalam saluran pencernaan kelinci. Sementara pada pakan dalam bentuk mash, karena memang sudah halus bentuknya, maka waktu yang dibutuhkan untuk mengecilkan partikel pakan hanya sebentar. Pakan yang lebih lama ber- jalan di dalam saluran pencernaan akan mengalami penyerapan nutrien yang lebih baik daripada pakan yang sebentar melewati saluran pencernaan, khususnya pada usus halus, tempat terjadinya penyerapan sari-sari makanan. Penyerapan sari-sari makanan terjadi pada villi (jonjot-jonjot) yang terdapat pada dinding usus. Makanan yang lebih lama berada dalam usus akan lebih lama bersinggungan dengan villi usus, akibatnya nutrien yang bisa dicerna menjadi lebih banyak daripada makanan yang sebentar berada dalam usus halus. Nutrien yang diserap lebih banyak pada pakan pelet akhirnya akan menghasilkan PPBH yang lebih tinggi daripada pakan mash.

Hasil penelitian ini sesuai dengan penelitian Lebas (1973) cit. Wiseman (1987). Pakan pelet pada penelitian tersebut menghasilkan $\mathrm{PBBH}$ sebesar $36 \mathrm{~g} /$ hari, sedangkan pakan mash menghasilkan 29,7 g/hari. Demikian juga penelitian 
Tabel 5. Hasil karkas kelinci jantan yang diberi konsentrat dalam bentuk pelet dan mash (carcass yield of rabbit bucks fed pellet and mash concentrates)

\begin{tabular}{lccc}
\hline \hline \multicolumn{1}{c}{ Variabel (variable) } & Pelet $($ pellet $)$ & Mash & Sig. \\
\hline Bobot potong (g) (slaughter weight $(\mathrm{g}))$ & $3.186,00 \pm 282,63$ & $2.975,00 \pm 155,20$ & $\mathrm{~ns}$ \\
Bobot karkas (g) (carcass weight $(\mathrm{g})$ ) & $1.569,40 \pm 136,99$ & $1.473 \pm 123,45$ & $\mathrm{~ns}$ \\
Persentase karkas (\%) (carcass percentage (\%)) & $49,28 \pm 1,40$ & $49,45 \pm 1,96$ & $\mathrm{~ns}$ \\
Bobot daging (g) (meat weight $(\mathrm{g})$ ) & $1.091,80 \pm 131,92$ & $1.011,75 \pm 78,61$ & $\mathrm{~ns}$ \\
Bobot tulang (g) (bone weight $(\mathrm{g})$ ) & $477,90 \pm 38,76$ & $461,25 \pm 56,86$ & $\mathrm{~ns}$ \\
Perbandingan daging dan tulang $($ Meat Bone Ratio) & $2,30 \pm 0,36$ & $2,21 \pm 0,22$ & $\mathrm{~ns}$ \\
\hline
\end{tabular}

${ }^{\mathrm{ns}}$ Non signifikan (non significant); ${ }^{*} \mathrm{P}<0,05$.

Machin et al. (1980) cit. Wiseman (1987), menunjukkan bahwa pakan pelet menghasilkan PBBH sebesar 33,1 g/hari, sedangkan pakan mash menghasilkan 26,5 g/hari.

Konversi pakan kelinci yang diberi konsentrat dalam bentuk pelet lebih rendah $(\mathrm{P}<0,05)$ daripada yang diberi konsentrat dalam bentuk mash (Tabel 3). Nilai konversi pakan yang lebih rendah pada pakan pelet disebabkan karena ADG yang dicapai oleh kelinci yang diberi pakan pelet lebih tinggi daripada yang diberi pakan mash, sementara konsumsi pakan kedua kelompok berbeda tidak nyata. Hal ini sesuai dengan penelitian Fomunyam dan Ndoping (2000) yang menyatakan bahwa konversi pakan konsentrat dalam bentuk pelet lebih rendah daripada pakan mash. Hal ini berarti konsentrat dalam bentuk pelet lebih efisien untuk meningkatkan bobot badan kelinci daripada konsentrat dalam bentuk mash. Hasil penelitian ini juga sesuai dengan penelitian Machin et al. (1980) cit. Wiseman (1987). Pakan pelet pada penelitian tersebut nilai FCR pakan pelet mencapai 3,3, sedangkan pada pakan mash 3,8. Demikian pula pada penelitian Lebas (1973) cit. Wiseman (1987) memberikan FCR pada pakan pelet 2,62, sedangkan pada pakan mash 2,78.

Pencapaian PBBH dan konversi pakan kelinci pada penelitian ini tidaklah sebaik pada penelitian sebelumnya. Hal ini mungkin disebabkan karena potensi genetik kelinci yang digunakan lebih baik dan/atau pakan yang digunakan memiliki kualitas yang lebih baik daripada penelitian ini.

Feed cost per gain kelinci yang diberi konsentrat dalam bentuk pelet lebih murah $(\mathrm{P}<0,05)$ daripada yang diberi konsentrat dalam bentuk mash. Meskipun harga konsentrat dalam bentuk pelet lebih mahal daripada pakan mash karena terdapat biaya proses pelleting, biaya proses tersebut telah terkompensasi oleh berbagai keuntungan (de Blas dan Wiseman, 2010), salah satunya adalah pencapaian PBBH yang lebih tinggi.

Bobot potong dan karkas, persentase karkas, bobot daging dan tulang, serta MBR pada kelinci yang diberi pakan dalam bentuk pelet dan mash berbeda tidak nyata (Tabel 5). Hal ini disebabkan karena konsumsi pakan konsentrat antara pelet dan mash juga berbeda tidak nyata. Proses pengolahan menjadi bentuk pelet tidak mengubah komposisi nutrien dari bentuk mash.

\section{Kesimpulan}

Hasil penelitian menunjukkan bahwa kelinci lebih menyukai konsentrat dalam bentuk pelet daripada mash. Pertumbuhan kelinci yang diberi konsentrat dalam bentuk pelet lebih baik daripada yang diberikan pakan mash. Perbedaan bentuk pakan tidak menyebabkan perbedaan hasil karkas. Hasil penelitian perlu dilanjutkan dengan penelitian yang lebih mendalam mengenai pakan dalam bentuk pelet sebagai pakan komplet untuk kelinci.

\section{Daftar Pustaka}

de Blas, C. and J. Wiseman. 2010. Nutrition of the rabbit. $2^{\text {nd }}$ Edition. $\mathrm{CAB}$ International. London.

Fomunyam, R.T. and B.N. Ndoping. 2000. Utilization of peleted and non peleted feed by growing rabbits in tropical conditions. World Rabbit Science 8 (2): 61-62.

Furuichi, M. 1988. Fish Nutrition and Mariculture. JICA textbook. The General Aquaculture Course. Kanagawa International Fisheries Training Center. Tokyo.

Manshur, F. 2009. Kelinci: Pemeliharaan secara Ilmiah, Tepat dan Terpadu. Nuansa cendekia. Bandung.

NRC. 1977. Nutrien Requirement of Rabbit. $2^{\text {nd }}$ revised edition. National Academy of Sciences, Washington D.C. p 10.

Sitorus, P., S. Soedirman, Y.C. Raharjo, I.G. Putu Santoso, B. Sudaryanto, dan A. Nurhadi. 1982. Budidaya peternakan kelinci di Jawa Barat. Laporan Pusat Penelitian dan Pengembangan Peternakan. Bogor.

Wiseman, J. 1987. Feeding of Non-Ruminant Livestock. Butterworth \& Co. Ltd. England. 